\title{
Corrigendum (2): Revisiting the Taxonomy of the Genus Arcobacter: Getting Order From the Chaos
}

\author{
Alba Pérez-Cataluña ${ }^{1}$, Nuria Salas-Massó ${ }^{1}$, Ana L. Diéguez ${ }^{2}$, Sabela Balboa ${ }^{2}$, \\ Alberto Lema ${ }^{2}$, Jesús L. Romalde ${ }^{2 *}$ and María J. Figueras ${ }^{1 *}$ \\ ${ }^{1}$ Departament de Ciències Mèdiques Bàsiques, Facultat de Medicina, Institut d'Investigació Sanitària Pere Virgili, Universitat \\ Rovira i Virgili, Reus, Spain, ${ }^{2}$ Departamento de Microbiología y Parasitología, CIBUS-Facultad de Biología, Universidade de \\ Santiago de Compostela, Santiago de Compostela, Spain
}

Keywords: Arcobacter, Aliiarcobacter gen. nov., Pseudoarcobacter gen. nov., Haloarcobacter gen. nov., Malacobacter gen. nov., Poseidonibacter gen. nov., taxonomic criteria

OPEN ACCESS

Edited by:

Martin G. Klotz,

Washington State University

United States

Reviewed by:

David W. Ussery,

University of Arkansas for Medical

Sciences, United States lain Sutcliffe,

Northumbria University,

United Kingdom

George Garrity,

Michigan State University,

United States

*Correspondence:

Jesús L. Romalde

jesus.romalde@usc.es

María J. Figueras

mariajose.figueras@urv.cat

Specialty section

This article was submitted to

Evolutionary and Genomic

Microbiology

a section of the journal

Frontiers in Microbiology

Received: 01 August 2019 Accepted: 17 September 2019

Published: 01 October 2019

Citation:

Pérez-Cataluña A, Salas-Massó N

Diéguez AL, Balboa S, Lema A,

Romalde JL and Figueras MJ (2019)

Corrigendum (2): Revisiting the

Taxonomy of the Genus Arcobacter:

Getting Order From the Chaos.

Front. Microbiol. 10:2253.

doi: 10.3389/fmicb.2019.02253

\section{A Corrigendum on}

Revisiting the Taxonomy of the Genus Arcobacter: Getting Order From the Chaos by Pérez-Cataluña, A., Salas-Massó, N., Diéguez, A. L., Balboa, S., Lema, A., Romalde, J. L., et al. (2018) Front. Microbiol. 9:2077. doi: 10.3389/fmicb.2018.02077

The original paper, which contained a description of five new genera with 25 species (all new combinations) contained many errors that prevented the proposed names from being included in a Validation List in the International Journal of Systematic and Evolutionary Microbiology. The List Editors could correct part of the problems, so that the generic names Pseudarcobacter, Malaciobacter. Halarcobacter, and Poseidonibacter and the species assigned as "comb. nov." to these genera could be validly published [Oren, A. and Garrity, G. M. (2019). List of new names and new combinations previously effectively, but not validly, published. Validation List no. 185. Int. J. Syst. Evol. Microbiol. 69, 5-9]. The corrections made are explained in footnotes to the list. However, because of the nature of some of the changes required, the List Editors could not make the corrections for the proposed genus "Aliiarcobacter" and the eight proposed new combinations in the Validation List. The corrigendum published [Revisiting the Taxonomy of the Genus Arcobacter: Getting Order From the Caos (sic), by Pérez-Cataluña, A., SalasMassó, N., Diéguez, A. L., Balboa, S., Lema, A., Romalde, J. L., et al. (2018). Front. Microbiol. 9:3123. doi: 10.3389/fmicb.2018.03123] failed to correct the remaining errors and introduced new problems. This necessitated a new Corrigendum in order to effectively publish the names Aliarcobacter and eight "comb. nov." species to be submitted subsequently for List validation in the International Journal of Systematic and Evolutionary Microbiology.

\section{Description of Aliarcobacter gen. nov.}

Aliarcobacter (A.li.ar.co.bac'ter. L. pronoun alius other, another; N.L. masc. n. Arcobacter a bacterial generic name; N.L. masc. n. Aliarcobacter the other Arcobacter). Cells are Gram-negative, curved rods $0.2-0.5 \mathrm{~mm}$ in diameter and $1-3 \mathrm{~mm}$ long. Motile by single polar flagellum. Does not swarm. Chemoorganotrophic. Oxidase and catalase positive. No growth occur at $4 \% \mathrm{NaCl}$. Growth occurs at $15^{\circ} \mathrm{C}-42^{\circ} \mathrm{C}$. Carbohydrates are not fermented. Nitrate usually reduced to nitrite. Positive for the hydrolysis of indoxyl acetate and negative for urease. Growth does not occur in the presence 2,3,5-triphenyltetrazolium chloride $(0.04 \%, \mathrm{wt} / \mathrm{vol})$ or glycine $(1 \% \mathrm{wt} / \mathrm{vol})$. Some species may grow in the presence of safranin $(0.05 \% \mathrm{wt} / \mathrm{vol})$ or oxgall $(1 \% \mathrm{wt} / \mathrm{vol})$. Fluorescent pigments are not produced. Some species are sensitive to cefoperazone $(64 \mathrm{mg} / \mathrm{l})$. Range of DNA GC+C content is 26.4-29.4 mol\%. The type species is Aliarcobacter cryaerophilus. 
Description of Aliarcobacter cryaerophilus comb. nov. Basonym: Campylobacter cryaerophila Neill et al. 1985.

The description is the same given by Neill et al. (1985). The type strain is A169/B $\mathrm{B}^{\mathrm{T}}\left(=\right.$ NCTC $11885^{\mathrm{T}}=$ ATCC $\left.43158^{\mathrm{T}}\right)$.

Description of Aliarcobacter butzleri comb. nov.

Basonym: Campylobacter butzleri Kiehlbauch et al. 1991.

The description is the same given by Vandamme et al. (1992). The type strain is LMG $10828^{\mathrm{T}}\left(=\mathrm{CDC} D 2686^{\mathrm{T}}=\operatorname{ATCC} 49616^{\mathrm{T}}\right)$.

Description of Aliarcobacter skirrowii comb. nov.

Basonym: Arcobacter skirrowii Vandamme et al. 1992.

The description is the same given by Vandamme et al. (1992). The type strain is Skirrow $449 / 80^{\mathrm{T}}$ $\left(=\right.$ LMG $6621^{\mathrm{T}}=$ CCUG $\left.10374^{\mathrm{T}}\right)$.

Description of Aliarcobacter cibarius comb. nov.

Basonym: Arcobacter cibarius Houf et al. 2005.

The description is the same given by Houf et al. (2005). The type strain is LMG $21996^{\mathrm{T}}\left(=\right.$ CCUG $\left.48482^{\mathrm{T}}\right)$.

\section{Description of Aliarcobacter thereius comb. nov.}

Basonym: Arcobacter thereius Houf et al. 2009.

The description is the same given by Houf et al. (2009). The type strain is LMG $24486^{\mathrm{T}}\left(=\right.$ CCUG $\left.56902^{\mathrm{T}}\right)$.

Description of Aliarcobacter trophiarum comb. nov. Basonym: Arcobacter trophiarum De Smet et al. 2011.

\section{REFERENCES}

De Smet, S., Vandamme, P., De Zutter, L., On, S. L. W., Douidah, L., and Houf, K. (2011). Arcobacter trophiarum sp. nov., isolated from fattening pigs. Int. J. Syst. Evol. Microbiol. 61, 356-361. doi: 10.1099/ijs.0.02 2665-0

Houf, K., On, S. L. W., Coenye, T., Debruyne, L., De Smet, S., and Vandamme, P. (2009). Arcobacter thereius sp. nov., isolated from pigs and ducks. Int. J. Syst. Evol. Microbiol. 59, 2599-2604. doi: 10.1099/ijs.0.006650-0

Houf, K., On, S. L. W., Coenye, T., Mast, J., Van Hoof, J., and Vandamme, P. (2005). Arcobacter cibarius sp. nov., isolated from boiled carcasses. Int. J. Syst. Evol. Microbiol. 55, 713-717. doi: 10.1099/ijs.0.63103-0

Neill, S. D., Campbell, J. N., O’Brien, J. J., Weatherup, S. T. C., and Ellis, W. A. (1985). Taxonomic position of Campylobacter cryaerophila sp. nov. Int. J. Syst. Bacteriol. 35, 342-356. doi: 10.1099/00207713-35-3-342

Vandamme, P., Vancanneyt, M., Pot, B., Mels, L., Hoste, B., Dewettinck, D., et al. (1992). Polyphasic taxonomic study of the emended genus Arcobacter with Arcobacter butzleri comb. nov. and Arcobacter skirrowii sp. nov.,
The description is the same given by De Smet et al. (2011). The type strain is $64^{\mathrm{T}} \quad\left(=\right.$ LMG $25534^{\mathrm{T}}$ $=$ CCUG $59229^{\mathrm{T}}$ ).

\section{Description of Aliarcobacter lanthieri comb. nov.}

Basonym: Arcobacter lanthieri Whiteduck-Léveillée et al. 2015.

The description is the same given by Whiteduck-Léveillée et al. (2015). The type strain is AF $1440^{\mathrm{T}}$ (= LMG $28516^{\mathrm{T}}=$ CCUG $66485^{\mathrm{T}}$ ).

\section{Description of Aliarcobacter faecis comb. nov.}

Basonym: Arcobacter faecis Whiteduck-Léveillée et al. 2016.

The description is the same given by Whiteduck-Léveillée et al. (2016). The type strain is AF1078 ${ }^{\mathrm{T}}$ (= LMG $28519^{\mathrm{T}}=$ CCUG $\left.66484^{\mathrm{T}}\right)$.

The first Corrigendum stated that the original article had been updated. This action was reversed with the publication of the Erratum. The authors apologize for this error and state that this does not change the scientific conclusions of the article in any way.

\section{ACKNOWLEDGMENTS}

The authors are indebted to Prof. Aharon Oren (Jerusalem, Israel) for expert guidance on following the rules on bacterial nomenclature as provided by The International Code of Nomenclature of Prokaryotes (ICNP).

an aerotolerant bacterium isolated from veterinary specimens. Int. J. Syst. Bacteriol. 42, 344-356. doi: 10.1099/00207713-42-3-344

Whiteduck-Léveillée, K., Whiteduck-Léveillée, J., Cloutier, M., Tambong, J. T., $\mathrm{Xu}, \mathrm{R}$., Topp, E., et al. (2015). Arcobacter lanthieri sp. nov., isolated from pig and dairy cattle manure. Int. J. Syst. Evol. Microbiol. 65, 2709-2716. doi: $10.1099 /$ ijs.0.000318

Whiteduck-Léveillée, K., Whiteduck-Léveillée, J., Cloutier, M., Tambong, J. T., Xu, R., Topp, E., et al. (2016). Identification, characterization and description of Arcobacter faecis sp. nov., isolated from a human waste septic tank. Syst. Appl. Microbiol. 39, 93-99. doi: 10.1016/j.syapm.2015.12.002

Copyright (C) 2019 Pérez-Cataluña, Salas-Massó, Diéguez, Balboa, Lema, Romalde and Figueras. This is an open-access article distributed under the terms of the Creative Commons Attribution License (CC BY). The use, distribution or reproduction in other forums is permitted, provided the original author(s) and the copyright owner(s) are credited and that the original publication in this journal is cited, in accordance with accepted academic practice. No use, distribution or reproduction is permitted which does not comply with these terms. 